\title{
Late Colon Involvement by Lobular Carcinoma of the Breast: A Diagnosis to Keep in Mind!
}

\author{
Miguel Bispo ${ }^{\mathrm{a}}$ Ricardo Rio-Tinto ${ }^{\mathrm{a}}$ Paulo Fidalgo $^{\mathrm{a}}$ Mireia Castillo-Martin ${ }^{\mathrm{b}}$ \\ Jacques Devière ${ }^{a, c}$ \\ a Department of Gastroenterology and Digestive Endoscopy, Champalimaud Foundation, Lisbon, Portugal; \\ ${ }^{b}$ Department of Pathology, Champalimaud Foundation, Lisbon, Portugal; ' Department of Gastroenterology, \\ Hepatopancreatology and Digestive Oncology, Erasme University Hospital, Université Libre de Bruxelles, Brussels, \\ Belgium
}

Keywords

Breast cancer · Invasive lobular carcinoma · Colonic metastases

\section{Envolvimento tardio do cólon por carcinoma lobular da mama: um diagnóstico a considerar!}

\section{Palavras Chave \\ Cancro da mama - Carcinoma lobular invasivo Metástases do cólon}

Breast cancer is a heterogeneous disease with two main types: invasive ductal carcinoma (the most frequent type) and invasive lobular carcinoma (that comprises approximately $10 \%$ of all cases) $[1,2]$. Lobular carcinoma is more than just a histologic variant of breast cancer, since it has distinct molecular, morphologic, biologic, and epidemiologic characteristics, which have clinical and prognostic implications [2].

\section{KARGER}

E-Mail karger@karger.com www.karger.com/pjg
(C) 2019 Sociedade Portuguesa de Gastrenterologia Published by S. Karger AG, Basel

Karger

0 pen access

This article is licensed under the Creative Commons AttributionNonCommercial-NoDerivatives 4.0 International License (CC BYNC-ND) (http://www.karger.com/Services/OpenAccessLicense). Usage and distribution for commercial purposes as well as any distribution of modified material requires written permission.
We report the case of a 60-year-old female with a medical history of invasive lobular carcinoma of the breast 12 years before. At that time, the patient was submitted to resection surgery and adjuvant chemotherapy. Recurrence-free survival was documented for 12 years. Due to recent onset of chronic diarrhea and weight loss, colonoscopy was performed and documented diffuse edema in-

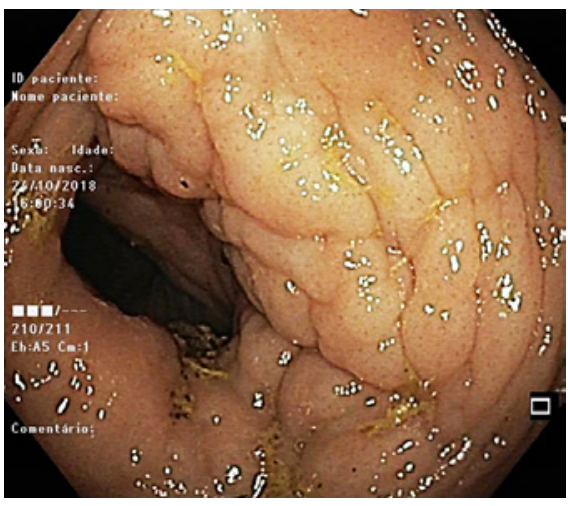

Fig. 1. Diffuse edema involving the ascending colon and ileocecal valve, with thick and rigid folds and without ulceration. 

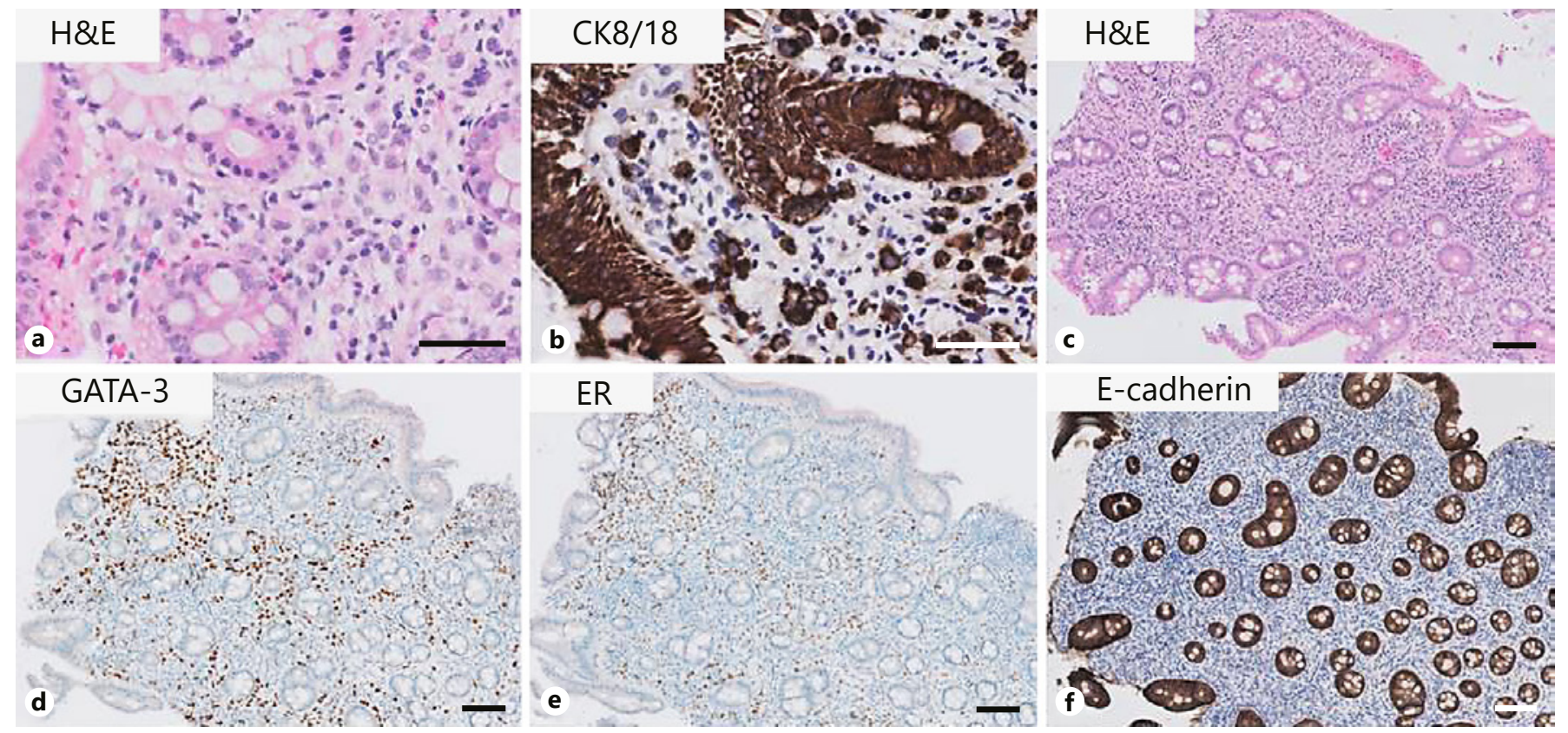

Fig. 2. Neoplastic infiltration of the colonic lamina propria. a Tumor cells are homogenous and relatively small and show a single-cell pattern of invasion. $\mathbf{b}$ CK8/18 highlights the presence of disperse neoplastic cells in the lamina propria. c-f Tumor cells show an immunohistochemical phenotype consistent with breast lobular carcinoma, with expression of GATA-3 (d) and estrogen receptor (ER; e), and loss of e-cadherin (f). Scale bars correspond to $100 \mu \mathrm{m}(\mathbf{a}, \mathbf{b})$ and $50 \mu \mathrm{m}(\mathbf{c}-\mathbf{f})$.

volving the right colon and the ileocecal valve with asymmetric thickening/hypertrophy and rigidity of the folds, without ulceration (Fig. 1). Pathology identified diffuse infiltration of the lamina propria by scattered small and homogeneous cells, with a immunohistochemistry profile consistent with primary lobular carcinoma of the breast (Fig. 2). Computed tomography documented peritoneal and right colon involvement with ascites. The patient is currently under palliative chemotherapy, with a favorable response on computed tomography evaluation.

Invasive lobular carcinoma of the breast has a less predictable pattern of metastatic spread than ductal carcinoma, frequently involving unusual sites such as the gastrointestinal tract (stomach, small bowel, and colon), the ovary, and the peritoneum [2-4]. Although lobular carcinoma usually has a more favorable response to therapy and a longer recurrence-free survival compared to ductal carcinoma, recurrence may occur more than 10 years following therapy [3]. In case series of colorectal metastases from lobular breast cancer, the average interval between the diagnosis of the primary tumor and colonic involvement was 7 years, but late recurrence, as late as 17 years following the diagnosis of the primary tumor, in resem- blance to the present case report, have been previously reported [5, 6]. An exceedingly late recurrence of lobular breast cancer presenting with gastric metastasis 23 years after the initial diagnosis and treatment has recently been described [7]. The infiltrating pattern of this tumor with scattered non-cohesive cells that lack cellular atypia infiltrating the submucosa, may result in false-negative results from endoscopic biopsies and delay the diagnosis [3, 5]. Keeping in mind the peculiar characteristics of invasive lobular carcinoma of the breast regarding gastrointestinal involvement might increase the diagnostic yield for its detection and allow prompt initiation of therapy.

\section{Statement of Ethics}

The authors have no ethical conflicts to disclose.

\section{Disclosure Statement}

The authors have no financial disclosures to report.
48

GE Port J Gastroenterol 2020;27:47-49 DOI: $10.1159 / 000497390$
Bispo/Rio-Tinto/Fidalgo/Castillo-Martin/ Devière 


\section{References}

1 Anderson WF, Matsuno R. Breast cancer heterogeneity: a mixture of at least two main types? J Natl Cancer Inst. 2006 Jul;98(14): 948-51.

2 Pestalozzi BC, Zahrieh D, Mallon E, Gusterson BA, Price KN, Gelber RD, et al.; International Breast Cancer Study Group. Distinct clinical and prognostic features of infiltrating lobular carcinoma of the breast: combined results of 15 International Breast Cancer Study Group clinical trials. J Clin Oncol. 2008 Jun; 26(18):3006-14.
3 Arpino G, Bardou VJ, Clark GM, Elledge RM. Infiltrating lobular carcinoma of the breast: tumor characteristics and clinical outcome. Breast Cancer Res. 2004;6(3):R149-56.

4 Mathew A, Rajagopal PS, Villgran V, Sandhu GS, Jankowitz RC, Jacob M, et al. Distinct Pattern of Metastases in Patients with Invasive Lobular Carcinoma of the Breast. Geburtshilfe Frauenheilkd. 2017 Jun;77(6):660-6.

5 Amin AA, Reddy A, Jha M, et al. Rectal metastasis from breast cancer: an interval of 17 years. BMJ Case Rep. 2011 May 12;2011.pii: bcr0120113683.
6 López Deogracias M, Flores Jaime L, AriasCamisón I, Zamacola I, Murillo Guibert J, Suescun García R, et al. Rectal metastasis from lobular breast carcinoma 15 years after primary diagnosis. Clin Transl Oncol. 2010 Feb;12(2):150-3.

7 Libânio D, Dinis-Ribeiro M, Pimentel-Nunes P. Gastric Metastasis of Breast Cancer after 20 Years. GE Port J Gastroenterol. 2018 Mar; 25(2):99-101. 